\title{
Discrimination between Workers of Acromyrmex subterraneus molestans from Monogynous and Polygynous Colonies
}

\author{
Danival José de Souza ${ }^{1}$, Terezinha Maria Castro Della Lucia ${ }^{1 *}$ and Luiz Cláudio de \\ Almeida Barbosa ${ }^{2}$ \\ ${ }^{I}$ Departamento de Biologia Animal; Centro de Ciências Biológicas e da Saúde; ${ }^{2}$ Departamento de Química; \\ Laboratório de Análise e Síntese de Agroquímicos; Universidade Federal de Viçosa; 36570-000; Viçosa - Minas \\ Gerais - Brasil
}

\begin{abstract}
Behavioral assays were conducted with individuals from monogynous and polygynous colonies of Acromyrmex subterraneus molestans to evaluate the discriminatory ability of ant workers. These bioassays showed that this subspecies could not discriminate among non-nestmates or nestmate workers. However, nestmates of these same colonies did discriminate among workers of another subspecies Ac. subterraneus subterraneus. When discrimation occurred there were no differences in the response of workers from either monogynous or polygynous colonies. Similarities or differences in the chemical profile of both subspecies explained the absence or occurence of aggressiveness among workers. The chemical profile of colonies of the same subspecies was very similar among them, although distinct among subspecies. The number of queens did not influence the cuticular chemical composition of the workers or their behavior.
\end{abstract}

Key words: Leaf-cutting ants, nestmate discrimination, polygyny

\section{INTRODUCTION}

The discriminatory ability of ants toward nestmates and non-nestmates is based on the fact that each colony has its own "chemical signature", a mixture of chemical compounds that is colony specific (Hölldobler and Michener, 1980). Nestmate recognition can be defined as the discriminatory capacity of workers to distinguish members of their own colony from others that are conspecifics (Vander Meer et al., 1989). Hydrocarbons constitute a considerable portion of cuticular lipids that avoid insect desiccation but are also important in the process of chemical communication (Howard and Blomquist 1982). It is generally assumed that within the Formicidae cuticular hydrocarbons (HCs) play an important role in nestmate recognition (Lahav et al., 1999). The harvester ant Pogonomyrmex barbatus is able to notice differences in the HCs composition during the process of nestmate recognition (Wagner et al., 2000). Greene and Gordon (2003) demonstrated that workers of this species used these hydrocarbons to inform a nestmate on a certain task to be executed. The individual production of $\mathrm{HCs}$ is dynamic and polymorphic (Vander Meer et al., 1989). Therefore, it is essential that nestmates

\footnotetext{
${ }^{*}$ Author for correspondence
} 
homogenize their $\mathrm{HCs}$ frequently to create a uniform colony-specific profile. In Camponotus fellah, social isolation of workers induced a divergence in the individual hydrocarbon profiles (Boulay et al., 2000). These authors reported that nestmates must continuously exchange their HCs via trophallaxis to obtain the Gestalt odor (Crozier and Dix, 1979). According to this Gestalt model, colony odor is formed by the mixture of individual odors from the queen and workers and those from environment.

The discrimination process in the ant Messor barbarus was studied in monogynous and polygynous laboratory colonies by Provost et al. (1994). They found that workers from monogynous colonies were more efficient in discriminating intruders than those from polygynous colonies. Similar results were obtained with Pseudomyrmex pallidus by Starks et al. (1998). The importance of the queen in worker recognition varies among ant species of distinct social structures (Lenoir et al., 1999). Based on a few studies on this aspect, two models have arisen. The first one, based on behavioral assays with Camponotus floridanus suggests that the queen is the main source of colony odor (Carlin and Hölldobler, 1987). The second model is based on biochemical studies in Cataglyphis niger and suggests that the queen acquires an average portion of all colony odors via grooming by the workers and becomes the center of the colony odor instead of its source (Lahav et al., 1998).

The objective of this study was to evaluate behavioral responses by workers of Acromyrmex subterraneus molestans from polygynous and monogynous colonies during encounters with adult workers from different colonies of the same subspecies. This should provide some information on the importance of queen number in the colony on the discrimination process of this leaf-cutting ant subspecies. Levels of aggressiveness were also evaluated by promoting encounters between workers of this subspecies and those of another leaf-cutting ant subspecies Acromyrmex subterraneus subterraneus. The chemical profile of the colonies was determined and related to the discrimination behavior. The hypothesis to be tested was that workers from polygynous colonies of Ac. subterraneus molestans were less aggressive against workers from other colonies (of same or distinct subspecies) than workers from monogynous colonies.

\section{MATERIALS AND METHODS}

Colony collection and maintenance in laboratory

The experiments were conducted with workers originated from four colonies of Ac. subterraneus molestans and two of Acromyrmex subterraneus subterraneus that were collected four months before the beginning of the tests in Viçosa, Minas Gerais State $\left(20^{\circ} 45^{\prime}\right.$ S, $\left.42^{\circ} 55^{\prime} \mathrm{W}\right)$. Two colonies of Ac. subterraneus molestans, named $M 7$ and $M 8$, were monogynous and two, $P 1$ and $P 2$, were polygynous with six and two queens, respectively. The two Ac. subterraneus subterraneus colonies, namely $E 1$ and $E 2$ were monogynous. The six colonies had approximately 13,000 individuals and the fungus garden 1.6 liters. They were placed in glass recipients of $1.7 \mathrm{~L}$ over a plastic tray $(42 \mathrm{x}$ $27 \times 7 \mathrm{~cm}$ ) where the workers had access to the foraging area, according to Della Lucia (1993). Room conditions were $25 \pm 2{ }^{\circ} \mathrm{C}, 75 \pm 5 \% \mathrm{R}$. H. and 10:14 L: D. The colonies were daily supplied leaves of Ligustrum sp. and Acalypha sp. and petals of Rosa sp. and Tecoma sp.

\section{Behavioral assays}

Discriminatory ability among adult $A c$. subterraneus molestans workers from polygynous and monogynous laboratory colonies.

Aggressiveness tests were conducted by means of encounters between an intruder (that was offered) and three non-nestmate workers aiming to estimate the discrimination level in Ac. subterraneus molestans. The intruder was marked with a dot of colored ink (Testors (C) on the gaster. The behavioral response of non-nestmate workers toward this marked ant was recorded. During the control tests, the four workers were nestmates and one was marked. These tests were important to show that the ink did not influence the behavior of the other ants.

The encounters were conducted in a Petri dish (90 $\mathrm{mm} \phi)$ during three minutes. Before each encounter, the marked ant was allowed to acclimate by isolating it in a glass tube inserted in the center of the Petri dish. Each encounter began by removing the glass tube and recording the reaction of the ants toward the marked nestmate according to the following index of aggression (Hefetz et al., 1996; Errard and Hefetz, 1997): 


$$
\mathrm{AI}=\frac{\sum_{i=1}^{n} A I_{i} * t_{i}}{T}
$$

where AI represents the aggression index, $t i$ the duration of each act and $\mathrm{T}$ the total interaction time defined as the sum of all times in which the ants interacted (had physical contact). A $i$ is a factor applied to each act according to the degree of aggressiveness: $\mathrm{AI} i=0$ (no aggressive interaction, antennal contact and grooming); $\mathrm{AI} i=$ 1 (mandibular opening and abdomen curling); $\mathrm{AI} i$ $=2$ (biting); and $\mathrm{AI} i=3$ fight and reciprocal mutilation. Thus, the index AI ranged from zero (no aggression) to 3 . The frequency and duration of each behavioral component was registered using the ODLog (Macropod software). The aggressiveness levels between polygynous colonies $(P \times P)$, monogynous colonies $(M \times M)$ and among monogynous and polygynous colonies $\left(\begin{array}{lll}M & \mathrm{x}\end{array}\right)$ of the subspecies Ac. subterraneus molestans were evaluated. Aggressiveness of workers originated from polygynous and monogynous colonies of this subspecies toward workers of another subspecies $(E 1, E 2)$ were also tested. The degrees of aggressiveness exhibited by each colony were tested by means of ANOVA and Tukey's test for the samples with different replication number at 5\% significance.

\section{Chemical analyses}

The chemical profile and identification of chemical compounds of each colony were determined by an extraction of cuticular components of 40 media workers. These workers were placed in $3 \mathrm{ml}$ of hexane during one hour at $50^{\circ} \mathrm{C}$, with slight agitation of the preparation at 5minute intervals. One mililiter of each extract was dried under $\mathrm{N}_{2}$ and the residue was redissolved in $50 \mu \mathrm{l}$ of chloroform. The samples were analyzed using a gas chromatograph-mass spectrometer (Shimadzu QP 5000.) The experimental conditions were: fused silica capillary column $(30 \mathrm{~m} \times 0.25$ $\mathrm{mm})$ with a DB5 bonded phase $(0.25 \mu \mathrm{m}$ film thickness), injector temperature $220^{\circ} \mathrm{C}$; detector temperature $240^{\circ} \mathrm{C}$; column program, $170-300^{\circ} \mathrm{C}$ at $3.25^{\circ} \mathrm{C} / \mathrm{min}, 300^{\circ} \mathrm{C}$ for $3 \mathrm{~min}$; carrier gas $\mathrm{He}$ $(1 \mathrm{~mL} / \mathrm{min})$; split ratio $1: 5$; volume injected $2 \mu \mathrm{L}$; initial column pressure 19.5 psi. The MS conditions were: impact energy $70 \mathrm{eV}$; scan speed 1000; acquisition mass range, $m / \mathrm{z} 45-650 \mathrm{Da} A$ standard mixture of several linear saturated alkanes (C18-C20, C22, C24, C26, C28, C30, C34, C36) (Sigma-Aldrich), was analyzed under the same conditions, and in this case the volume injected was $1 \mu \mathrm{l}(10 \mathrm{mg} / \mathrm{ml}$ in chlorophorm $)$ and the split ratio of 50:1. This procedure aimed to help in identification of the cuticular compounds. The methodology of extraction and analyses of the cuticular chemical compounds was adapted from Wagner et al. (1998).

\section{Data analyses}

The relative abundance of each compound was estimated as the proportional area to each peak in the chromatogram. All compounds which represented at least $1 \%$ of the total abundance were included in the statistical analysis. A hierarchical cluster analysis was used to separate the colonies (Ward's Method, Pearson's r coefficient, Statistica 5.5). The method of Ward or of the Minimum Variance is distinct from others because it uses the square sums of any two groups that may be formed at each iteration of the algorithm. Pearson's correlation coefficient measures the degree of correlation between two variables. It is given by the following formula:

$$
\mathrm{r}_{\mathrm{rm}}=\frac{\sum_{\mathrm{i}=1}^{\mathrm{I}}\left(\mathrm{x}_{\mathrm{in}}-\overline{\mathrm{x}}_{\mathrm{n}}\right) \times\left(\mathrm{x}_{\mathrm{im}}-\overline{\mathrm{x}}_{\mathrm{m}}\right)}{\sqrt{\sum_{\mathrm{i}=1}^{\mathrm{I}}\left(\mathrm{x}_{\mathrm{in}}-\overline{\mathrm{x}}_{\mathrm{n}}\right)^{2} \sum_{\mathrm{i}=1}^{\mathrm{I}}\left(\mathrm{x}_{\mathrm{im}}-\overline{\mathrm{x}}_{\mathrm{m}}\right)^{2}}}
$$

where $n$ and $m$ are the two variables. The degree of significance of the correlations was tested at 5\% probability.

\section{RESULTS AND DISCUSSION}

Discrimination ability of the workers of $A c$. subterraneus molestans

No aggressive reaction was observed during the encounters of Ac. subterraneus molestans workers against marked individuals of the same subspecies, whether or not nestmates. The aggression level of workers could not be associated to the number of queens in the colony since the value of the aggression index was zero $(\mathrm{AI}=0)$. 
Workers from monogynous ( $M 7$ and $M 8)$ and from polygynous colonies $(P 1$ and $P 2)$ were not aggressive against conspecifics of other colonies. During these encounters, in all cases, the only act observed among the workers was the antennal touch, which lasted less than one second. These workers moved constantly around the Petri dish and encounters as well as antennal touch seemed casual. According to Obin (1986),

Crossland (1989) and Tissot et al. (2001) ant colonies maintained in the laboratory tend to be less aggressive towards each other than those recently collected in the field.
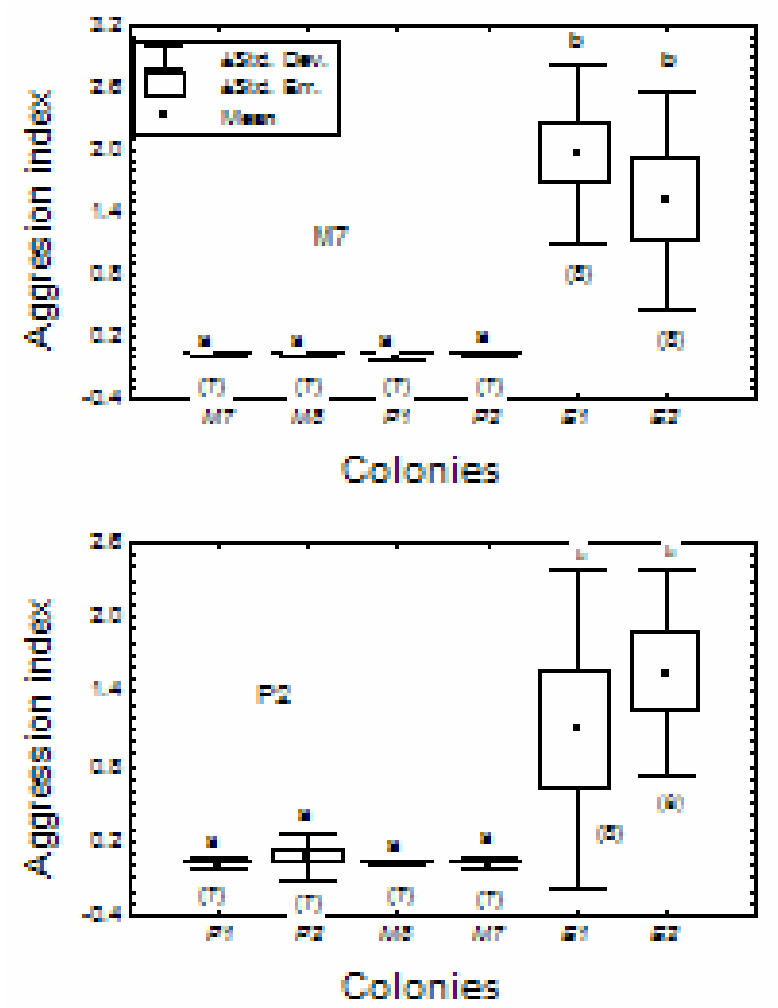

Acromyrmex subterraneus molestans workers from monogynous and polygynous laboratory colonies exhibited hostile behavior against workers of another subspecies Ac. subterraneus subterraneus. In the majority of the encounters fights and mutual mutilation occurred. The mean aggressiveness index exhibited by colonies of Ac. subterraneus molestans was between 1 and 2 (Fig. 1). When the hostile response occurred, the behavior of the four colonies did not differ significantly (ANOVA; $\mathrm{F}_{3,60}=0.707, \mathrm{p}=0.55$ ), that is, the mean aggressiveness level against colonies $E 1$ and $E 2$ was equal for all of them (Fig. 2).
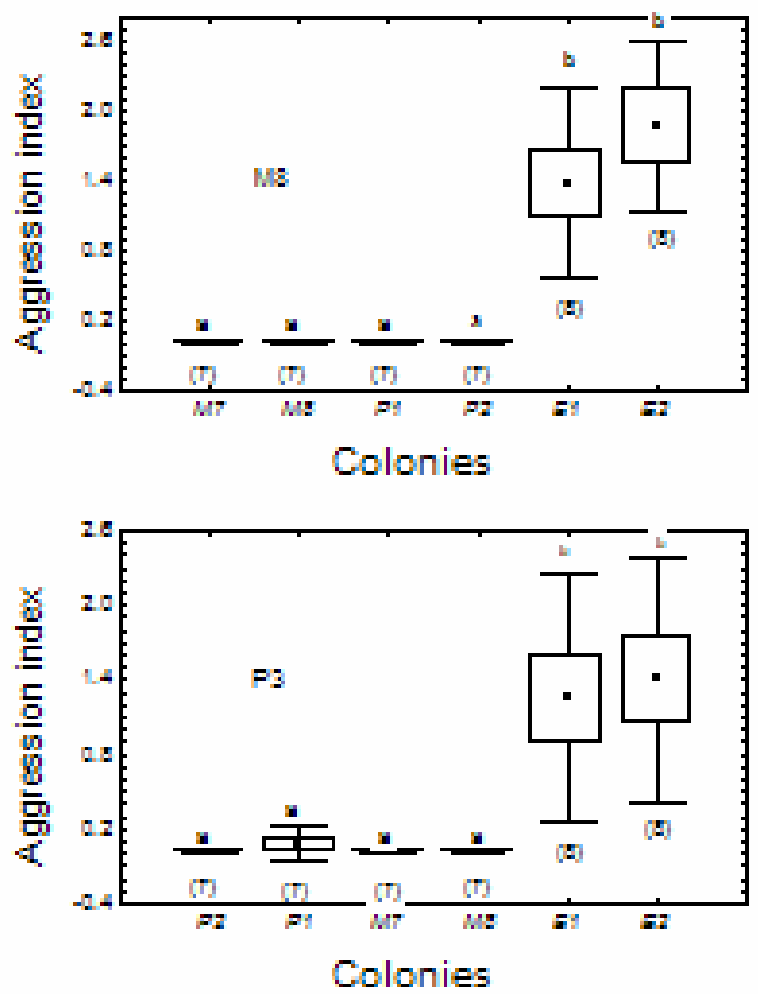

Figure 1 - Mean aggressiveness level of polygynous (P1/P2) and monogynous (M7/M8) colonies of $A c$. subterraneus molestans. E1 and E2 represent the behavior of workers of two monogynous colonies of another subspecies Ac. subterraneus subterraneus. Means followed by the same letter do not differ statistically by Tukey's test for different values of $\mathrm{N}$ at $5 \%$ significance. The number of observations is in parenthesis. 


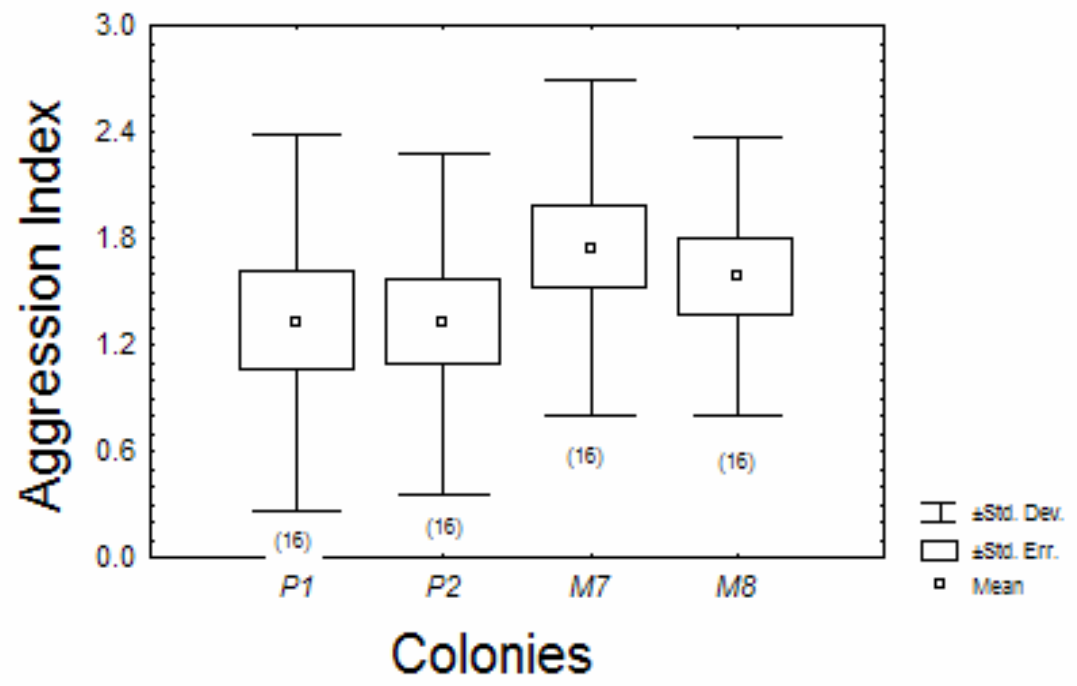

Figure 2 - Mean aggressiveness level of workers of Ac. subterraneus molestans (P1, P2, M7 and M8) against workers of the subspecies Ac. subterraneus subterraneus (E1 and E2). Means did not differ at $5 \%$ significance level (ANOVA); $\mathrm{F}_{3,60}=0.707, \mathrm{p}=0.55$ ).

During the fights among workers of the two subspecies, most of the times both aggressed and aggressor released faecal liquid. This material interrupted the fight temporarily. Bernasconi et al. (2000) investigated the role of faecal liquid released by virgin queens of Apis mellifera during fights of these queens. According to these authors, the function of the faecal liquid would be decreasing the aggressiveness so that the queen that released this material had better chances of winning the fights without greater injury. Bernasconi et al. (1999) had earlier characterized chemically this faecal material. It has been reported that the faecal liquid of some Attini ants is composed mainly of enzymes (Martin et al. 1975) which may be derived from the fungus (Boyd and Martin, 1975). In larvae of the leafcutting ant Atta sexdens rubropilosa, this liquid contain proteins, glucose and free amino acids, all of which are of considerable nutritional value (Schneider, 2003). According to this author, as soon as the larva expels faecal material the first worker that finds it by antennal touch ingests it immediately. However, how this faecal liquid affects the workers behavior in leaf-cutting ants other than proctodeal trophallaxis has not been investigated so far.

\section{Chromatogram analyses}

Workers of monogynous and polygynous colonies of Ac. subterraneus molestans have a very similar chemical cuticular profile, so that there exists no qualitative differences between them as revealed by the chromatograms (Fig. 3). On the other hand, colonies of Ac. subterraneus subterraneus exhibit qualitative differences in the chemical profile when compared to those in Ac. subterraneus molestans. The analyses of the retention times of the standards of linear alkanes showed that the cuticular hydrocarbons of the subspecies studied have from 25 to 36 carbon atoms in their structure as those obtained by Wagner et al. (1998) for Pogonomyrmex barbatus. It could also be said that no cuticular hydrocarbon corresponded to those of the standard mixture of linear hydrocarbons $(\mathrm{C} 18$, $\mathrm{C} 19, \mathrm{C} 20, \mathrm{C} 22, \mathrm{C} 24, \mathrm{C} 28, \mathrm{C} 30, \mathrm{C} 34$ and C36). As the molecular ions were not evident from the mass spectra of the compounds, a complete structure elucidation was not possible, but from the fragmentation pattern, it was clear that they were hydrocarbons, most of them being branched.

The schematic representation of the clusters obtained by the Hierarchical Cluster analyses performed based on 68 detected peaks of the six colonies demonstrated the separation of two groups (Fig. 4). The first group was formed by colonies of the subspecies Ac. subterraneus subterraneus (E1 and E2), and Pearson's 
correlation coefficient was significant at $5 \%$ level for two colonies. The second group was formed by the colonies of the subspecies Ac. subterraneus molestans, in which both monogynous ( $M 7$ and $M 8)$ and polygynous ( $P 1$ and $P 2)$ colonies were grouped and had a significant correlation coefficient at $5 \%$ level of probability. There was no significant correlation among colonies of the distinct subspecies.
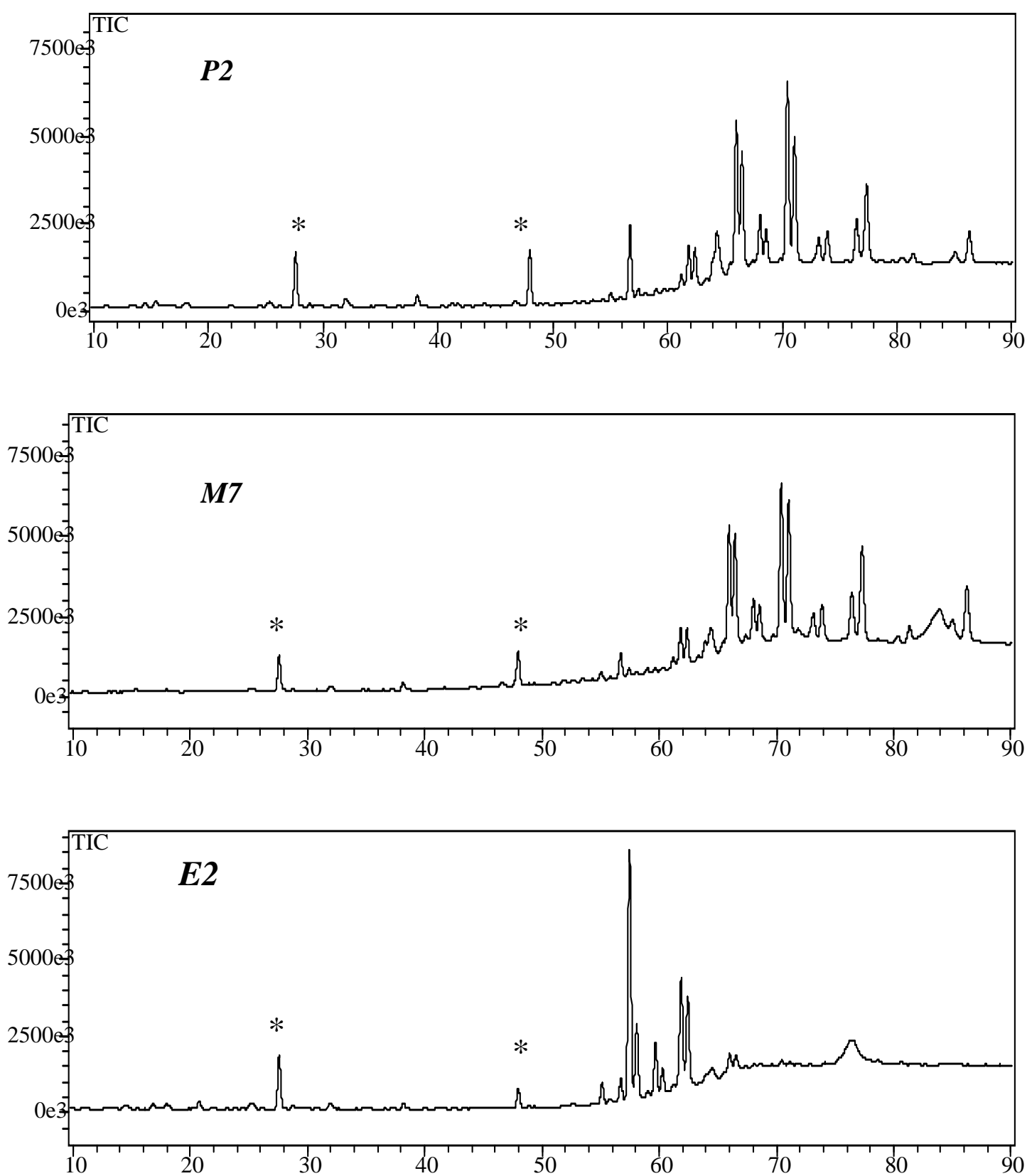

Figure 3 - Chromatograms of the chemical cuticular profile of Ac. subterraneus molestans workers from a polygynous $(P 2)$ and monogynous $(M 7)$ colonies. E2 represents the chromatogram of a colony of the subspecies Ac subterraneus subterraneus. The asterisks indicate contaminants originated from the phtalic acid. 
There was evidence that workers from polygynous colonies exhibited lower dis-criminating ability against intruders (Provost et al., 1994; Vienne et al., 1998; Starks et al., 1998). In Pseudomyrmex pallidus, for example, Starks et al. (1998) found a negative correlation between the number of queens present in the colony and the level of aggression exhibited by the workers. In the present study, workers from polygynous colonies were not less aggressive than those from monogynous colonies. Jutsum et al. (1979) reported that environmental factors such as the diet supplied to the colonies were more important in triggering the aggressive behavior in Acromyrmex octospinosus than endogenous factors. Thus, the fact that the same plant material was supplied to all colonies could explain the lack of aggressiveness among them. On the other hand, the analyses of the cuticular hydrocarbons which was under genetic control, demonstrated that these compounds have little variation between colonies. The hydrocarbon composition was very distinct, with consequent aggressiveness reaction when the other subspecies was analyzed. It could be possible that colonies from the same region might have less variation in the loci which determined hydrocarbon production. Thus, aggression tests involving colonies of different sizes and from different regions could provide a better understanding on the discrimination behavior in Acromyrmex subterraneus molestans.

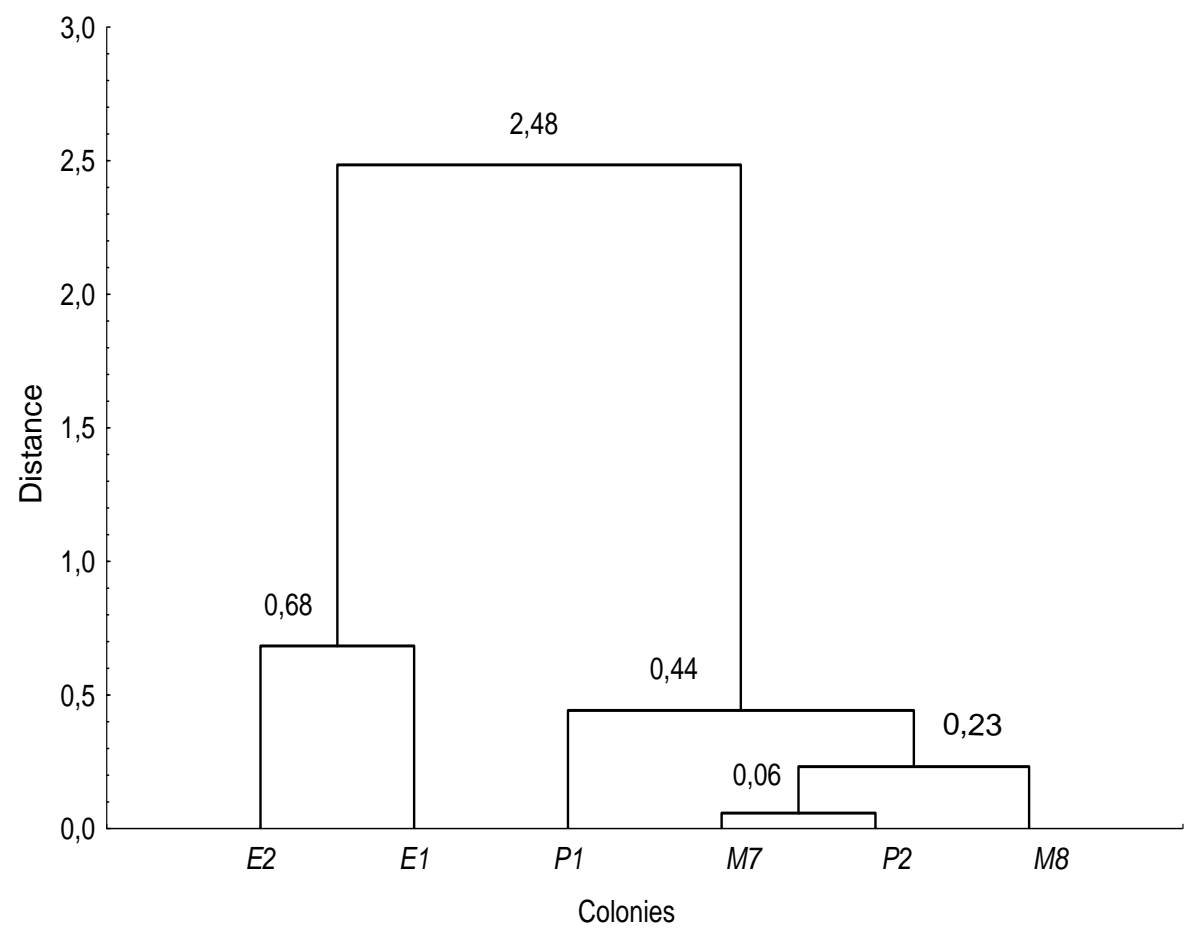

Figure 4 - Hierarchical cluster analysis (Ward's Method, Pearson's Distance) conducted in the relative proportion of 68 peaks showed in the chromatograms of the cuticular extracts of the workers from monogynous (M7 and M8) and polygynous ( $P 1$ and $P 2$ ) colonies of Ac. subterraneus molestans and Ac. subterraneus subterraneus (E1 and E2). Only peaks of relative proportion greater than or equal to $1 \%$ were used in this analysis.

The utilization of another subspecies was an important parameter to evaluate the behavior of workers of Ac. subterraneus molestans. It also indicated that the composition of cuticular hydrocarbons was a character which separated these two subspecies that were sympatric in the region of Viçosa. The main morphological characters used to separate the three subspecies of Ac. subterraneus (the two studied here and Ac. subterraneus brunneus) were the ant body color and the form of the lower lateral pronotal spine (Santschi, 1937). This, according to Fowler and 
Ketelhut (1993), was extremely variable. Besides the great morphological similarity, the two subspecies studied have the same chromosomal number $(2 \mathrm{n}=38)$ (Fadini and Pompolo, 1996) and their spermatozoa did not seem to have any morphological differences (personal observation). One could speculate that the cuticular hydrocarbon composition would be a means of reproductive isolation of these subspecies. This could be similar to what happens with Drosophila mojavensis, a fly that feeds on cactus and whose reproductive isolation mechanism involves differentiated hydrocarbon profiles of populations feeding on different substrates (Fogleman and Danielson, 2001). It also could be somewhat similar to the mechanisms occurring in close species of moths which were reproductively isolated from each other by the concentration of the compounds in the same blend of sexual pheromones (Kaae et al.,1973).

This study showed that the number of queens in colonies of Acromyrmex subterraneus molestans did not have an influence on the discriminatory behavior of the worker. The similar hydrocarbon profile of the colonies was responsible for the lack of aggressiveness among workers of the same subspecies but of distinct colonies. On the other hand, workers of Ac. subterraneus molestans were able to discriminate workers of another subspecies with distinct cuticular hydrocarbon profiles. They exhibited aggressive behavior towards workers of Ac. subterraneus subterraneus but there were no differences in hostile behavior in workers originated from either polygynous or monogynous colonies.

\section{ACKNOWLEDGEMENTS}

This paper is part of the M.Sc. thesis of the first author. The authors were supported by Conselho Nacional de Desenvolvimento Científico e Tecnológico - CNPq grants.

\section{RESUMO}

Ensaios comportamentais foram conduzidos com indivíduos de colônias monogínicas e poligínicas de Acromyrmex subterraneus molestans a fim de avaliar a habilidade discriminatória de suas operárias. Estes bioensaios mostraram que esta subespécie não é capaz de discriminar entre não companheiras e companheiras de ninho. Entretanto, companheiras de mesma colônia discriminam operárias pertencentes à outra subespécie, Ac. subterraneus subterraneus. Nesta situação, não houve diferença na resposta de operárias oriundas de colônias monogínicas e poligínicas. Similaridades ou diferenças no perfil químico de ambas as subespécies podem explicar a ausência ou presença de agressividade entre operárias. O perfil químico de colônias de mesma subespécie foi muito similar entre si e muito distinto entre subespécies. O número de rainhas não influenciou a composição química cuticular das operárias e nem o seu comportamento discriminatório.

\section{REFERENCES}

Bernasconi, G.; Bigler, L.; Hesse, M. and Ratnieks, F. L. W. (1999), Characterization of queen-specific components of the fluid released by fighting honey bee queens. Chemoecology, 9, 161-167.

Bernasconi, G.; Ratnieks, F. L. W. and Rand, E. (2000), Effect of "spraying" by fighting honey bee queens (Apis mellifera L.) on the temporal structure of flights. Insectes Sociaux, 47, 21-26.

Boulay, R.; Hefetz, A.; Soroker,V. and Lenoir, A. (2000), Camponotus fellah colony integration: worker individuality necessitates frequent hydrocarbon exchanges. Animal Behaviour, 59, 1127-11333.

Boyd, N. D. and Martin, M. M. (1975), Faecal proteinases of the fungus-growing ant Atta texana: their fungal origin and ecological significance. Journal of Insect Physiology, 21, 1815-1820.

Carlin, N. F. and Hölldobler, B. (1987), The kin recognition system of carpenter ants (Camponotus spp.). II. Larger colonies. Behavioral Ecology and Sociobiology, 20, 209-217.

Crosland, M. W. J. (1989), Intraspecific aggression in the primitive ant genus Myrmecia. Insectes Sociaux, 36, 161-172.

Crozier, R.H. and Dix, W. (1979), Analysis of two genetic models for the innate components of colony odor in social Hymenoptera. Behavioral Ecology and Sociobiology, 4, 217-224.

Della Lucia, T. M. C. (1993), As formigas cortadeiras. Viçosa: Folha de Viçosa.

Errard, C. and Hefetz, A. (1997), Label familiarity and discriminatory ability of ants reared in mixed groups. Insectes Sociaux, 44, 189-198.

Fadini, M. A. M. and Pompolo, S. D. G. (1996), Cytogenetics of some ant species of the tribe Attini (Hymenoptera, Formicidae) from the region of Viçosa. Brazilian Journal of Genetic, 19, 53-55. 
Fogleman, J. C. and Danielson, P. B. (2001), Chemical interactions in the cactus microorganism -Drosophila model system of the Sonoran Desert. American Zoologist, 41, 877-899.

Fowler, H. G. and Ketelhut, S. M. (1993), Confusão taxonômica: variação clinal, inter e intrapopulacional em Acromyrmex subterraneus (Hymenoptera: Formicidae). In: Encontro de Mirmecologia/IV International Symposium on Pest Ants, Belo Horizonte. Anais ... Belo Horizonte.

Greene, M. J. and Gordon, D. M. (2003), Cuticular hydrocarbons inform task decisions. Nature, 423, 32.

Hefetz, A.; Errard, C.; Chambris, A. and Le Negrate, A. (1996), Postpharyngeal gland secretion as a modifier of aggressive behavior in the Myrmicinae ant Manica rubida. Journal of Insect Behavior, 9, 719-717.

Hölldobler, B. and Michener, C. D. (1980), Mechanisms of identification and discrimination in social Hymenoptera. In: Markl, H. (Ed.). Evolution of social behavior: hypotheses and empirical tests. Chemie Gmbh, Weinheim. pp. 35-38.

Howard, R. W. and Blomquist, G. J. (1982), Chemical ecology and biochemistry of insect hydrocarbons. Annual Review of Entomology, 27, 149-172.

Jutsum, A.R.; Saunders, T. S. and and Cherrett, J. M. (1979), Intraspecific aggression in the leaf-cutting ant Acromyrmex octospinosus. Animal Behavior, 27, 839-844.

Kaae, R. S.; Shorey, H. H. and and Gaston, L. K. (1973), Pheromone concentration as a mechanism for a reproductive isolation between two lepidopterous species. Science, 179, 487-488.

Lahav, S.; Hefetz, A. and Vander Meer, R. K. (1998), Nestmate recognition in the ant Cataglyphis niger: do queen matter? Behavioral Ecology and Sociobiology, 43, 203-212.

Lahav, S.; Soroker, V.; Hefetz, A. and Vander Meer, R K. (1999), Direct behavioral evidence for hydrocarbons as ant recognition discriminators. Naturwissenschaften, 86, 246-249.

Lenoir, A.; Fresneau, D.; Errard, C. and Hefetz, A. (1999), Individuality and colonial identity in ants: the emergence of the social concept. In: Detrain, C.; Deneuborg, J. L. and Pasteels, J. M. (Eds.). Information processing in social insects. Boston: Birkhauser. pp. 219-237.

Martin, M. M.; Boyd, N. D.; Gieselmann, M. J. and Silver, R. G. (1975), Activity of faecal fluid of a leafcutting ant toward plant cell wall polysaccharides. Journal of Insect Physiology, 21, 1887-1892.

Obin, M. S. (1986), Nestmate recognition cues in laboratory and field colonies of Solenopsis invicta Buren (Hymenoptera: Formicidae). Journal of Chemical Ecology, 12, 1965-1975.
Provost, E.; Rivière, G.; Roux, M.; Bagnéres, A. G. and and Clément, J. L. (1994), Cuticular hydrocarbons whereby Messor barbarus ant workers putatively discriminate between monogynous and polygynous colonies. Are workers labeled by queens? Journal of Chemical Ecology, 20, 2895-3003.

Santschi, F. (1937), Note sur Acromyrmex subterraneus Forel (Hym. Formicidae). Revista de Entomologia, 7 : (2/3), 230-233.

Schneider, M. O. (2003), Comportamento de cuidado com a prole na saúva-limão Atta sexdens rubropilosa Forel, 1908 (Hymenoptera: Formicidae). MSc Thesis, UNESP, Rio Claro, SP.

Starks, P. T.; Watson, R. E.; Matthew, J. D. and Dipaola, C. (1998), The effect of queen number on nestmate discrimination in the facultatively polygynous ant Pseudomyrmex pallidus (Hymenoptera: Formicidae). Ethology, 104, 57-584.

Tissot, M.; Nelson, D. R. and Gordon, D. M. (2001), Qualitative and quantitative differences in cuticular hydrocarbons between laboratory and field colonies of Pogonomyrmex barbatus. Compounds Biochemistry and Physiology, 130B, 349-358.

Vander Meer, R. K.; Saliwanchik, D. and Lavine, B. (1989), Temporal changes in colony cuticular hydrocarbon patterns of Solenopsis invicta: Implications for nestmate recognition. Journal of Chemical Ecology, 15, 2115-2125.

Vienne, C.; Errard, C. and Lenoir, A. (1998), Influence of the queen on worker behaviour and queen recognition behaviour in ants. Ethology, 104, 431-446.

Wagner, D.; Brown, M. J. F.; Broun, P.; Cuevas, W.; Moses, L. E.; Chao, D. L. and Gordon, D. M. (1998), Task-related differences in the cuticular hydrocarbon composition of harvester ants, Pogonomyrmex barbatus. Journal of Chemical Ecology, 12, 2021-2037.

Wagner, D.; Tissot, M.; Cuevas, W. and Gordon, D. M. (2000), Harvester ants utilize cuticular hydrocarbons in nestmate recognition. Journal of Chemical Ecology, 26, 2245-2257.
Received: August 24, 2004; Revised: February 22, 2005; Accepted: August 16, 2005. 